Pre-proof version. Manuscript accepted for publication in Discourse \& Communication.

\title{
Metaphor and Intertextuality in Media Framings of the (1984-1985) British Miner's Strike: A Multimodal Analysis
}

Christopher Hart (Lancaster University)

c.hart@lancaster.ac.uk

\begin{abstract}
The British Miners' Strike of 1984-1985 represents one of the most pivotal periods in British industrial relations. Media stance toward the miners remains a controversial issue today, as attested by recent publications looking back at the strike (Williams 2009a, 2014). Here, authors including miners, journalists and other commentators argue that media coverage of the strike followed a consistently anti trade union agenda in which the media sought to destabilise the strike. An internal BBC report only recently made public shows that the BBC themselves had concerns over possible imbalances in their coverage of the so-called 'Battle of Orgreave' (Harcup 2014). Despite the weight attached to media coverage in this context, however, surprisingly little research has been conducted from a discourse-analytical perspective to show systematically and empirically how such an agenda may have been manifested across media texts. In this paper, drawing on Critical Cognitive Linguistics, I show how one particular metaphorical framing of the strike, which construed the strike as a war between the State and the National Union of Miners, persisted through the year long period and consider the potential ideological functions of this framing in media strategies of (de)legitimation. I show how this metaphor featured in linguistic, visual and multimodal forms of media representation.
\end{abstract}

Keywords: multimodal metaphor, framing, news photographs, British miners' strike

\section{Introduction}

The 1984-1985 British Miners' Strike was an industrial action in the UK coal industry primarily affecting the North of England, Wales and Scotland. It was the largest strike to take place in Britain since the 1926 General Strike. The strike, which began on $6^{\text {th }}$ March 1984 and ended when miners returned to work on 3 March 1985, was a response to the closure of pits and the belief that the Government planned for further closures and ultimately the complete dismantling of the UK coal industry. The strike lead to bitter disputes between Margaret Thatcher, the then Prime Minister, and the National Union of Mineworkers (NUM) led by Arthur Scargill. However, following a series of strikes across the public sector in the 1970s which, leading to the 'winter of discontent', the previous Labour government had been unable to prevent, the Miners' Strike came to be symbolic of a wider ideological struggle between the Conservative government and trade union movements more generally. The strike resulted in communities being polarised and mining families enduring serious poverty. The strike ultimately ended in defeat for the miners leaving the Government free to embark on its programme of pit closures. The last deep coal mine in Britain closed in December 2015. Many mining areas of Britain remain affected by both pit closures and the politics of the strike.

A number of controversies surrounded the strike. For example, the strike proceeded through a series of local walkouts rather than on the back of a national ballot. This lead to so-called 'flying pickets' as miners from one area would travel to picket still operational mines in other areas. The disruptive picketing, in turn, lead to the mobilisation of police officers from around the country, including the metropolitan police, in key areas of Yorkshire and Nottinghamshire. A number of 
Pre-proof version. Manuscript accepted for publication in Discourse \& Communication.

violent encounters between police officers and striking miners followed. Two miners died as a direct result of the strike. In a bid to bring the strike to an end, the government withheld welfare payments for 'dependents' of striking miners. The assets of the NUM were also sequestered. Throughout the strike, financial support was leant by Russian miners leading Thatcher to claim, with the Cold War still ongoing, that Scargill had close ties with the Russian government. One of the biggest controversies surrounding the strike, however, concerned its portrayal in the media with many perceiving a sustained and systematic bias in both the print and broadcast media which, with its power to shape public opinion, contributed in a significant way to the outcome of the strike (see Williams 2009a, 2014). Williams (2009b: 39) writes that "the cumulative impact of the propaganda assault on the miners by the overwhelming majority of the national newspapers was to present to their readers over several months a totally distorted view of the strike". As one example of such controversy, in May 1984, The Sun planned on publishing a front page with a picture taken of Scargill at a rally in Mansfield with his arm outstretched in a pose reminiscent of Adolf Hitler. The picture was to be accompanied by the headline 'Mine Fuhrer'. The printers, however, refused to put this copy into production and on 15 May the paper appeared instead with the picture and headline replaced by the following statement on plain background: "Members of all The Sun production chapels refused to handle the Arthur Scargill picture and major headline on our lead story. The Sun has decided, reluctantly, to print the paper without either" (see Figure 1).

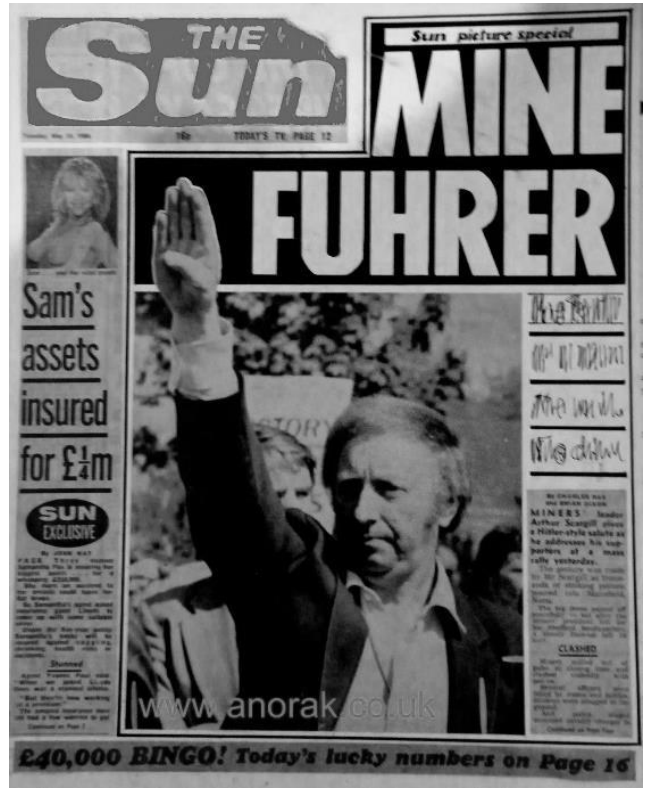

(a) Planned page

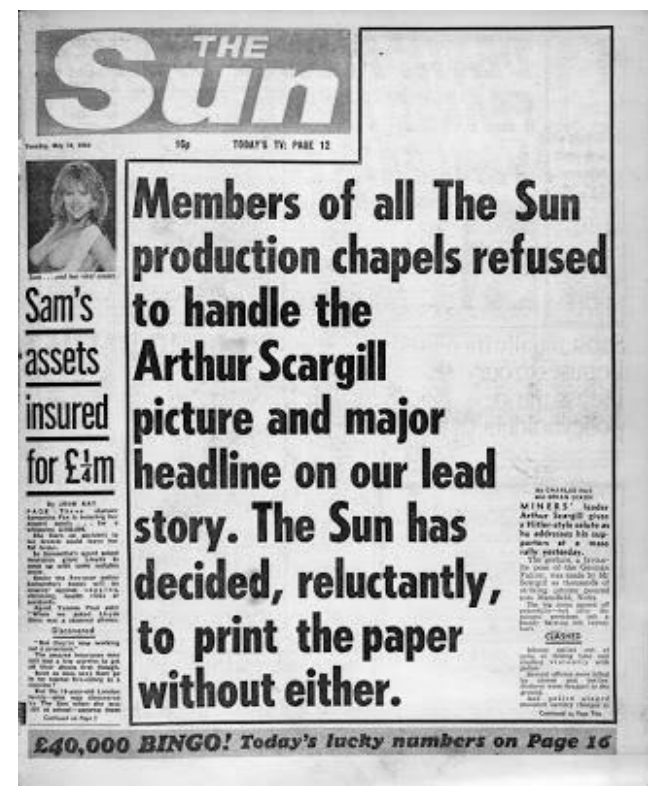

(b) Published page

Figure 1. The Sun, 15 May 1984

The picture, in conjunction with the reference to Hitler in the headline, presents a framing of the strike as a war as it connects with historical knowledge of World War II. In spite of the controversy surrounding this particular edition of The Sun, this metaphorical framing was in fact a persistent feature of media discourses throughout the strike.

Despite the significance of the Miners' Strike, both as a pivotal point in British industrial history and subsequently as a salient point of cultural reference, very little discourse-analytical research has 
Pre-proof version. Manuscript accepted for publication in Discourse \& Communication.

been conducted into media representations of the action. One well-known exception is found in Montgomery (1995). Although Montgomery noted a distinctly militaristic vocabulary in the reporting of the Daily Mail, whereby pickets 'stage an ambush' and 'bombard the police' who in turn 'send in the mounted brigade on two flanks' and 'charge dramatically', his analysis was primarily a transitivity analysis directed at "differences in the way that the respective roles of participants were actually constructed in the syntax of different newspaper accounts" (p. 241). No comprehensive or systematic study has been made of the way metaphor featured in media discourses during the year long strike. This is true of metaphor as it is expressed in both linguistic and visual modes of communication. In this paper, I focus on the role of metaphor as a framing device and show how a metaphoric framing of the British miners' strike as a war between the Government and the NUM persisted in linguistic, visual and multimodal media representations.

\section{Metaphor and Framing}

In Cognitive Linguistics metaphor is regarded not primarily as a linguistic phenomenon but as a cognitive process of frame projection which is reflected in and effected through metaphorical expressions in discourse (Lakoff and Johnson 1999; Fauconnier and Turner 2002). From this cognitive perspective, metaphor is a matter of construal in which one frame is selected to provide structure to another inside a system of conceptual metaphors. The essence of metaphor, as Lakoff and Johnson (1980: 5) state, is therefore "in understanding and experiencing one kind of thing in terms of another".

Frames are conceptual structures representing particular areas of knowledge and experience (Fillmore 1982, 1985). They are open-ended, encyclopaedic structures that serve as the cognitive 'base' against which semantically associated words are 'profiled' and understood (Langacker 1987). Frames exist at different levels of generality such that one frame may be seen as a more specific instantiation of another frame, which is therefore included within its meaning. Frames are modelled in terms of a set of defining semantic roles, or frame elements, which are constitutive of a general situation- or event-type. FrameNet (Ruppenhofer et al. 2010) distinguishes between core elements, which are essential to the meaning of a frame, and non-core elements, which do not uniquely characterise the frame but which nevertheless may be a salient feature of it. In discourse, frames are accessed or activated by references, explicit or implicit, to the frame or its aspects. They serve to give meaning and coherence to any text by providing a conceptual schema in terms of which the referential situation may be understood. In linguistic discourse, a frame is typically accessed via verbs or nominalisations denoting action elements within it. However, in principle, any aspect of the frame invoked in the course of discourse provides an access point to the rest of the frame, information encoded in which may contribute to meaning construction and affect.

In metaphors, embodied or culturally salient frames are selected to provide structure to otherwise unfamiliar or underspecified frames. From a Critical Cognitive Linguistic perspective (Charteris-black 2004; Chilton 1996; Dirven, Frank and Pütz 2003; Dirven, Polzenhagen and Wolf 2007; Hart 2010, 2011, 2015; Koller 2004; Musolff 2004, 2006; Semino 2008; Stockwell 1999), metaphor is therefore an important framing device which defines how social situations and events are to be understood, reasoned about, and reacted to emotionally. Metaphor may give rise to a further number of framing effects where the cognitive processes involved have consequences in directing decisions and, ultimately, actions. Metaphors accentuate certain aspects of a situation while simultaneously obfuscating others. In so doing, they problematize situations in specific ways, promote particular solutions to those 'problems', and pave the way for actions which accord with the metaphor. As 
Pre-proof version. Manuscript accepted for publication in Discourse \& Communication.

Semino (2008: 91) puts it: "the choice of one metaphor rather than another has consequences for how a particular issue is 'framed' or structured, which aspects are foregrounded and which are backgrounded, what inferences are facilitated, what evaluative and emotional associations triggered, what courses of action appear to be possible and so on". Metaphorical expressions in discourse are thus an important focus point in the study of ideology, as it is encoded cognitively in systems of conceptual metaphors, and the legitimation of social action (Koller 2005a: 206).

There is now a large body of research examining the framing functions of metaphor across a variety of social and political discourses. There is not space to review this literature in detail. For present purposes, two things are worthy of note. First, certain frames are found to have a high degree of 'multivalency' (Goatly 2007). That is, they are recruited to provide structure in the conceptualisation of different situation or event-types across a range of public discourses. One such frame is the WAR frame. The second thing worth noting is that metaphor as a cognitive process is not restricted in its operation to discourses articulated in the verbal modality but may equally be found to function in discourses articulated through the visual (or for that matter the auditory) channel (Forceville 2002, 2006, 2008; Forceville and Urios-Aparisi 2009). In some cases, a weak metaphorical framing in one modality is strengthened by a metaphorical framing in another accompanying modality while in other cases a metaphorical framing arises specifically as the result of a co-textual interaction between expressive forms in two different modalities. I discuss these two points in more detail below.

\subsection{The WAR frame in Public Discourse}

As Semino (2008) observes, the WAR frame is particularly wide in scope, at least in Anglo-American English, where it may be metaphorically applied to "any domain of experience that involves difficulties, danger, effort and uncertain outcomes" (p. 100). For example, the WAR frame has been found to play a metaphoric structuring role in a range of different discourses from business discourses around mergers and acquisitions (Koller 2005a) to medical discourses of cancer and end of life care (Demmen et al. 2015). In the domain of politics, Semino (2008: 100) points out that the WAR frame is conventionally used "in relation to conflict between individuals, groups, parties, and governments and oppositions". For example, in the national press, immigration is frequently framed as an act of war (Hart 2010). This framing is realised in expressions such as 'the invasion of Britain by illegal immigrants' (The Sun, 17.02.2002), 'the army of asylum seekers flooding into Britain' (Daily Mail, 04.03.2003) and 'the front line of the battle against illegal immigration' (Daily Mail, 14.12.2005).

The WAR frame invoked by expressions such as these is made up of a number of structural properties. For example, the WAR frame instantiates, and therefore entails, a more general frame for VIOLENT ENCOUNTER which, in turn, entails an OPPOSITION frame. Inherited from these more basic frames or schemas, the WAR frame includes core elements of two opposing groups of actors, military actions, and some purpose or issue at stake (i.e. what the war is being fought for/over). The frame necessarily involves perspective and construes one opposing participant as the aggressor and the other as the victim. The WAR frame further includes a number of non-core elements relating, for example, to time, place, manner, means, and duration. In framing a situation in terms of the WAR frame, core-elements are necessarily projected onto the target situation giving rise to 'metaphoric entailments' (Lakoff and Johnson 1980) while non-core elements are made available for projection leading to further potential inferences. Frames are further associated with more evaluative or affective concepts. In the WAR frame, these include concepts of danger, justice, and responsibility. These aspects of the general WAR frame are summarised in Table 1. 
Pre-proof version. Manuscript accepted for publication in Discourse \& Communication.

\begin{tabular}{|c|c|c|}
\hline Entails frames & $\begin{array}{l}\text { VIOLENT ENCOUNTER } \\
\text { OPPOSITION }\end{array}$ & \\
\hline Elaborated in frames & $\begin{array}{l}\text { WWI } \\
\text { WWII } \\
\text { COLD WAR }\end{array}$ & \\
\hline Core frame elements & $\begin{array}{l}\text { Participants } \\
\text { Processes } \\
\text { Purpose/Issue }\end{array}$ & $\begin{array}{l}\text { Army, soldiers } \\
\text { Invade, attack, launch, peace talks } \\
\text { Fight for freedom }\end{array}$ \\
\hline $\begin{array}{l}\text { Non-core frame } \\
\text { elements }\end{array}$ & $\begin{array}{l}\text { Time } \\
\text { Place } \\
\text { Manner } \\
\text { Instrument/Means } \\
\text { Duration }\end{array}$ & $\begin{array}{l}\text { War of 1914-1918 } \\
\text { Battle of Trafalgar } \\
\text { Bloody war } \\
\text { Tanks, guns } \\
30 \text { years war }\end{array}$ \\
\hline $\begin{array}{l}\text { Associated concepts / } \\
\text { scripts }\end{array}$ & $\begin{array}{l}\text { Danger } \\
\text { Justice/injustice } \\
\text { Responsibility }\end{array}$ & \\
\hline
\end{tabular}

Table 1. Aspects of the WAR frame

Framing an issue like migration as a war, then, is likely to achieve a number of framing effects. Not only are many of the structural properties of the WAR frame inherited by the IMMIGRATION frame, giving rise to an US-THEM opposition, but the framing is also likely to trigger particular evaluative and emotional responses where immigrants and asylum seekers, like invading armies, are seen as an enemy to be feared. As Semino (2008: 100) states, "the use of WAR metaphors tends to dramatize the opposition between different participants in politics (who are constructed as enemies), and to emphasize the aggressiveness and seriousness of political debates, conflicts or elections". The framing, moreover, has consequences for action. As El Refaie (2001: 368) points out, conceptualising immigrants as a dangerous enemy seems "to justify a war-like reaction to them".

The WAR frame is similarly mobilised in media discourses of political protests. For example, Fridolfsson (2008) studied two anti-globalisation protests in Gothenburg and in both cases found the metaphor DEMONSTRATION IS WAR to be widespread in media framing efforts. In the UK context, the same metaphor was found to feature in media reports of the 2009 G20 protests and the 2010 Student Fee protests (Hart 2014a/b). Conceptualising political demonstrations as war not only serves to demonise the protesters but, as it translates into action, the metaphor "establishes the plausibility for military intervention when dealing with political protest" (Fridolffsson 2008: 138).

Where frames are derived from experience, including culturally mediated experience, the generic WAR frame may be instantiated or elaborated in frames for specific, culturally salient, wars. For British citizens, this is most likely to be based on collective memories of World War I and World War $\mathrm{II}$, which are most widely taught in schools and referenced in popular television, film and literature etc. The WAR framing may therefore be realised through references or allusions to the particular elements (people, places, and events etc.) that make up war-specific frames. Thus, a World War II frame, for example, is likely to be invoked by references to Churchill, Hitler, Normandy, or the Battle of Britain. In this case, not only are the structural properties of the generic WAR frame, entailed by the more specific WORLD WAR II frame, projected onto the target situation but additional event- 
Pre-proof version. Manuscript accepted for publication in Discourse \& Communication.

specific knowledge is also projected and emotions associated with those specific historical moments activated.

World War II in particular is shown to be a rich source which frequently features in media framings. For example, Kelsey (2015) analysed media responses to the July $7^{\text {th }} 2005$ bombings in London. Immediate reports described the event as the 'worst attacks since the Second World War' (Independent, 08.07.2005) which caused 'the biggest disruption since the Second World War' (Daily Mail, 08.07.2005). Although these are not strictly metaphorical realisations, Kelsey points out that such examples set the "discursive conditions that made other Second World War analogies acceptable from 8 July onwards" (2015: 77). He shows that, within this discursive environment, (mythical) memories of 'the Blitz sprit' were continually drawn upon to construct the reactions of Londoners as defiant, stoic, resilient etc. One way this metaphorical framing was realised was through headlines making intertextual references to well-known propagandistic slogans of the Second World War, such as 'London can take it' and 'business as usual'. These intertextual references not only evoke a World War II frame to make sense of the events described but seem to be particularly effective in arousing emotions associated with World War II. Kelsey (2015: 81) further notes the significance of pictures of St Paul's Cathedral which featured as part of these reports:

St Paul's is an iconic symbol that is part of Britain's national narration. Whilst the area around it was completely destroyed during the Blitz, St Paul's itself remained undamaged. This image of it standing among the smoke from bombs falling around it is a metaphoric symbol of resilience; it is seen to be representative of the pride and defiance that Londoners supposedly express when under attack.

Pictures of St Paul's Cathedral, in other words, equally served to enact the metaphorical war framing through intertextual references in the visual modality. Intertextuality is therefore defined as the appropriation of or allusion to prior texts, linguistic and visual, in order to elicit a frame for understanding the situations described or depicted in the current text. When those texts belong to a different frame to the target situation, intertextuality provides a vehicle for metaphorical interpretation.

\subsection{Modes of Metaphor}

According to cognitive metaphor theory, metaphor is "primarily a matter of thought and action and only derivatively a matter of language" (Lakoff and Johnson 1980: 153). It is therefore to be expected that a given metaphorical framing should find expression across communicative modalities. The WAR frame shown above to feature in verbal articulations of different discourses is equally found to function in visual and multimodal articulations of those same discourses (e.g., El Refaie 2003; Koller 2005b, 2009). In visual depictions of two political demonstrations in Sweden, for example, Fridolfsson (2008: 137) notes that the news photography was "charged with visual references to war aesthetics like people hunching down in the streets or frightened faces taking protection in a smoky environment". There is now a growing body of research which recognises the visual and multimodal, as well as purely verbal, performance of underlying conceptual metaphors (Bounegru and Forceville 2011; Forceville 1996; Forceville 2002, 2006, 2008; Forceville and UriosAparisi 2009). Forceville's (2008) work offers the clearest typology of metaphorical realisation involving the visual modality: 
Pre-proof version. Manuscript accepted for publication in Discourse \& Communication.

- Pictorial metaphor 1: Contextual - in which a depicted entity is metaphorised by virtue of the visual context in which it is placed

- Pictorial metaphor 2: Hybrid - in which two objects that are normally distinct are depicted merged into a single 'gestalt'

- Pictorial simile - in which two objects are represented as independent items but are made to look similar in some way

- Multimodal metaphor - in which the source and target frames are cued in more than one modality.

Visual or pictorial metaphor often involves visual forms of intertextuality, whereby the surrounding visual context in which the target element is placed or the new gestalt created resembles or is reminiscent of a specific image within the source frame, which, as a consequence, is brought to bear in the conceptualisation. This may be an actual image such as a famous painting or an iconic, mythologised image in collective cultural memory (Werner 2004). Here we may distinguish a further form of pictorial metaphor:

- Pictorial metaphor 3: Holistic - in which the entity or event depicted is, as a whole, reminiscent of a particular image in the source frame.

We see this latter form of visual metaphor in the picture of Arthur Scargill in Figure 1(a). The distinction between a pictorial metaphor of this kind and multimodal metaphor, however, can be rather blurred. In multimodal metaphor, where it is most often the target frame that is presented in an image while the source frame is supplied in linguistic co-text, the metaphorical interpretation arises only by an interaction between representations in the two modalities. In many cases, though, the image alone may be enough for readers to recognise the comparison but, as in the complete newspaper page in Figure 1(a), the metaphorical framing is reinforced through accompanying language, which may also work by means of intertextuality. In such cases, following Barthes (1977), the linguistic co-text is said to provide an 'anchor' for the image which, in case of any ambiguity, "helps me to choose the correct level of perception, permits me to focus not simply my gaze but also my understanding" (Barthes 1977: 39). Where images are necessarily more open to interpretation and dependent on the reader's own subjectivity, the linguistic co-text serves to direct the reader "through the signifieds of the image, causing him to avoid some and receive others" and "towards a meaning chosen in advance" (Barthes 1977: 40). In newspaper layouts, the most immediate co-text is usually found in captions while other salient co-text is provided by headlines and lead paragraphs.

The majority of research in multimodal metaphor has been directed at genres such as advertising, branding and political cartoons (Bounegru and Forceville 2011; Foceville 1996, 2002; El Refaie 2003, 2009; Koller 2005b, 2009; Schilperoord and Maes 2009; Yus 2009), which do not purport to document reality. Comparatively little has been written in relation to genres such as news photography. News photography is traditionally thought to serve a documentary function, evidencing the 'realities' described verbally in the text (Bednarek and Caple 2012: 112). It is certainly true that photographs capture real happenings and make at least an implicit claim to truth and objectivity. More recently, however, it is recognised that news photographs, in their content, composition and co-textual embedding etc., construct and evaluate the realities they depict, serving as symbolic representations with emotional appeal (ibid.). Where Bounegru and Forceville (2011: 210) state that it is important to focus analyses "on discourses in a specific genre, since genre is a crucial framing device governing the interpretation of metaphors", this paper addresses metaphor in news photographs specifically. 
Pre-proof version. Manuscript accepted for publication in Discourse \& Communication.

\section{Data}

Data was collected from the Newsroom archives of the British Library. ${ }^{1}$ Six major events in the yearlong strike period were identified and the data oriented to these. The data centred on instances of violence between police and picketing miners rather than, for example, legal milestones. The six major events were:

- $12.03 .1984-$ Beginning of strike

- 15.03.1984 - Death of miner David Jones

- 18.03.1984 - Mass mobilisation of police forces

- 29.05.1984 - First use of police riot gear at Orgreave coking plant, Sheffield

- 18.06.1984 - 'Battle of Orgreave'

- 04.03.1985 - Strike ends, miners return to work

Eight national newspapers are included in the sample: the Daily Mail, the Daily Mirror, the Daily Express, The Sun, the Times, the Telegraph, the Guardian and the Morning Star. For each newspaper, all pages covering the events were selected from first editions published the following day or two days later in cases where the story continued to run. The data was subject to an initial manual parsing in order to identify recurrent themes, instantiations of which were then qualitatively analysed within the framework of cognitive and multimodal metaphor theory.

\section{Analysis}

From the very start of the period, the strike was explicitly framed as a war by the national press. The $13^{\text {th }}$ March headline in The Sun, for example, read 'PIT WAR: Violence erupts on the picket line as miner fights miner'. The image on the front page shows a woman waving a toy pistol (see Figure 2). On page 2 , the headline and lead paragraph read: ${ }^{2}$

\section{PIT WIWES SMASH PICKET INVASION}

A mum's army of miners' wives did battle with 200 of Arthur Scargill's flying pickets yesterday ... and won. The angry housewives squared up to massed ranks of spitting, snarling pickets and cheered their men safely into work. (The Sun, 13.03.1984)

\footnotetext{
${ }^{1}$ Due to the age and multimodal nature of the texts involved, electronic services like Lexis Nexis were not available.

${ }^{2}$ Capitals and bold face are preserved from original format. Underlining indicates metaphorical expressions.
} 


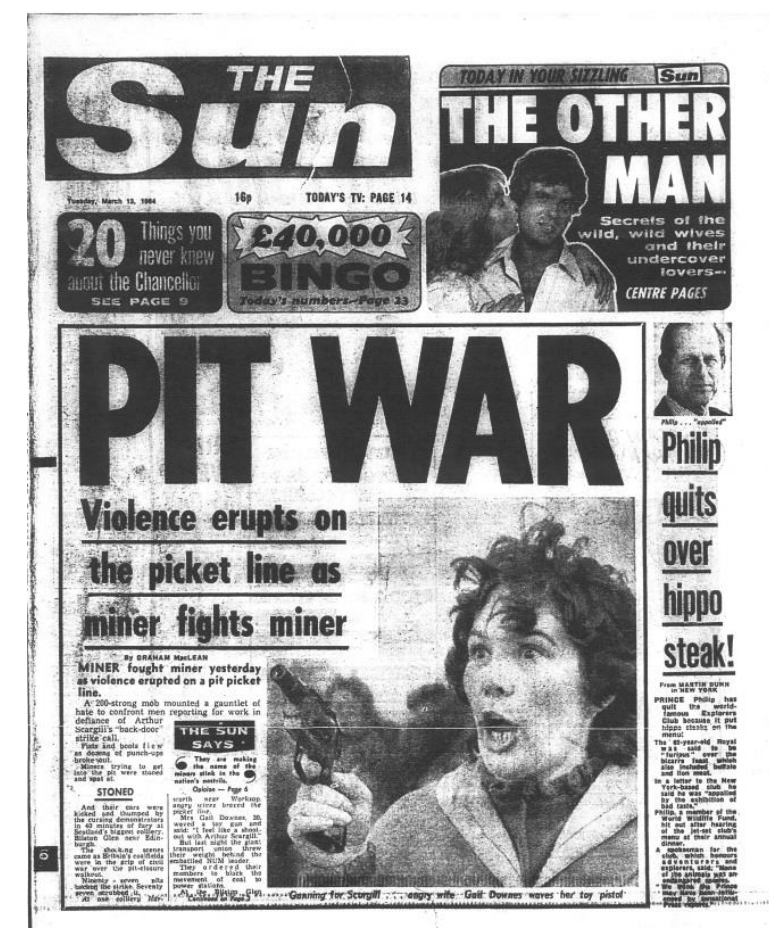

Figure 2. Front cover of The Sun at the beginning of the strike

(The Sun, 13.03.1984)

Headlines and lead paragraphs are especially important in providing a frame for understanding. Not only are they are visually salient, often appearing in large and bold print, but, as van Dijk (1988) observes, they serve to express the semantic macro-structure of the text. In relevance-theoretic terms, headlines "direct the reader to construct the optimal context for interpretation" (Dor 2003: 695). This may explain why metaphors tend to occur with high degrees of density at the beginning of a text where they serve to set the agenda for the proceeding discourse (Koller 2004: 55). Other direct references to the strike as a war occurred in headlines following the death of David Jones on $15^{\text {th }}$ March and the mass mobilisation of police forces on the $18^{\text {th }}$ March:

\section{(2) Crushed to death in Scargill's picket war}

The 24-year-old miner collapsed during violence at the Ollerton colliery early yesterday, only minutes after he had gone to the aid of another injured pitman. Despite the tragedy, Yorkshire miners' leaders have refused to call off their rampaging armies of pickets - in defiance of a High Court ban. Six hundred of them were out in force the night Mr Jones died at the besieged Nottinghamshire pit. (Daily Express, 16.03.1984)

\section{8,000 cops on alert to foil pits war}

An army of 8,000 police were at battle stations last night - ready for the final bust up with Arthur Scargill's flying pickets in the bloody pit war (The Sun, 19.03.1984)

In the examples above, the WAR frame is accessed by the lexical item 'war' within the headlines but also via other elements of the frame fulfilled in the lead paragraphs including PARTICIPANTS ('a mum's army of miners' wives', 'an army of 8,000 police', 'armies of pickets'), PROCESSES ('invade', 'rampage', 'besiege') and MANNER ('bloody pit war'). 
Pre-proof version. Manuscript accepted for publication in Discourse \& Communication.

With WAR providing a structuring frame, other frame-based knowledge becomes available to construe aspects of the target situation. Events within the strike become conceptualised as 'battles'. For example, violence at Thoresby pit, near Ollerton, was referred to by The Sun as the 'battle of Thoresby Colliery' (16.03.1984). In fact, this was a persistent discursive practice in relation to instances of violence across the media and throughout the strike, most notoriously in the so-called 'battle of Orgreave'. 'Battle of $X$ ' is a highly conventionalised construction within the WAR frame, which it accesses via the element PLACE. Similarly, military roles get assigned to participants with Scargill fulfilling the role of a 'general' or 'dictator'; negotiations between Government, the Coal Board and the NUM are construed as 'peace talks'; and the miners agreeing to return to work is seen as an act of 'surrender' marking 'defeat' for the NUM.

(4) Arthur Scargill stood like an army general surveying his warring troops in the bloody battle of Orgreave yesterday. (Daily Express, 19.06.1984)

(5) Howling down of a 'dictator' (Daily Mail, 16.03.1984)

(6) The crucial peace talks expected to begin today will be held in Yorkshire (Daily Mail, 31.05.1984)

(7) Surrender came on a tight 98-91 vote by an NUM delegate conference at the TUC headquarters in London. (The Sun, 04.03.1985)

(8) Traitors! The cry from a defeated army (Daily Mail, 04.03.1985)

The examples above all come from right-wing tabloid newspapers. It is worth noting, however, that although the broadsheet newspapers, the left-leaning Daily Mirror, and the socialist newspaper The Morning Star were less explicit in framing the strike as a war, avoiding the lexical item 'war' in direct reference to the strike, they similarly maintained a war framing by invoking aspects of the frame, in both language and image, as well as through other pragmatic strategies.

In avoiding any direct reference to the strike as a war, the Times, for example, described the Battle of Orgreave as the "worst violence in a British industrial dispute since the war" (The Times, 19.06.1984). The utterance presupposes that the two events are similar enough for the comparison to be valid and thus attributes to the target situation properties sourced from the WAR frame. Events at Orgreave are also described in language generally evocative of war:

(9) Amid fumes and explosions from smoke bombs, thunder-flashes and firecrackers, two convoys of 34 lorries raced through the mass picket with supplies for blastfurnaces. (The Times, 30.05.1984)

(10) The police were at first overwhelmed by the pickets but then re-grouped to advance under a hail of stones, bottles and bricks until the demonstrators retreated behind a barricade of burning cars, lamp posts and stones from a wall they had demolished (The Times, 19.06.1984)

This, also, was a pattern found across the press. Such representations serve to dramatize the events by inviting the reader to imagine the situation in a way that recalls news footage of recent war zones (see Hart 2016 on simulation semantics and critical discourse analysis). Indeed, the Guardian describes its photographers in terms associated with war reporting:

(11): Guardian photographer Don McPhee was in the front line of yesterday's picket at Orgreave coking plant, near Sheffield. (Guardian, 30.05.1984). 
Pre-proof version. Manuscript accepted for publication in Discourse \& Communication.

These linguistic examples all serve to establish a set of discursive conditions in which images of the strike are readily interpretable in terms of a WAR frame. In many cases, this framing is reinforced through the headlines or captions that accompany news photographs. However, even in the absence of any such co-text, the wider discursive context acts as an 'attractor' pulling the image into a dynamic metaphorical system (Cameron 2007; Gibbs and Cameron 2008). ${ }^{3}$ It is therefore not just the intra-textual context but the inter-textual context which is brought to bear in the interpretation of images. Here we may distinguish three levels of textual or discursive context. Immediate intratextual context, following El Refaie (2003: 86), is any language located in proximity to the image and which is intended to be read in direct conjunction with it. Prototypically, this would include captions. Surrounding intra-textual context refers to all other related items of text that appear on the same page or within the same document. Inter-textual context refers to the body of texts which have gone before as part of the unfolding news story.

Pictures of the miners strike which have a potential metaphorical reading seem to access the WAR frame via three main elements: PLACE, PARTICIPANTS and INSTRUMENT/MEANS.

\subsection{PLACE}

The locations where violent interactions between police and striking miners took place were depicted as battlefields reminiscent of World War I and World War II. In Figure 3, for example, the fallen sign suggests the devastation to land left by war. The caption that accompanies the image as it was published in the Daily Mirror reinforces the war framing by referring to the location shown as a 'battleground':

(12) BATTLEGROUND: Uprooted sign and broken walls (Daily Mirror, 19.6.1984)

In The Sun, the same image appeared with a headline directly above it: "Army of hate rains missiles on the police" (The Sun, 19.06.1984).

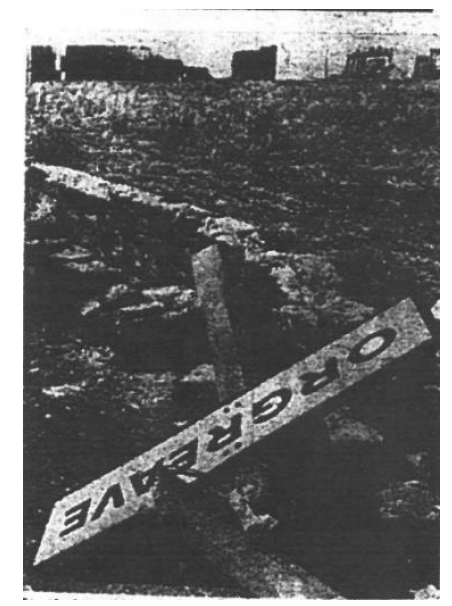

Figure 3. Fallen sign at 'Battle of Orgreave' (Daily Mirror, 19.6.1984)

\footnotetext{
${ }^{3}$ In processing terms, the WAR frame is made salient within the current cognitive environment and thus, for any image that may potentially access the WAR frame, this framing is likely to be the most 'relevant' and so the one satisfied in discourse (Sperber and Wilson 1995).
} 
Pre-proof version. Manuscript accepted for publication in Discourse \& Communication.

Similarly, the image in Figure 4 is reminiscent of the barbed wire barricades used in particular in World War I. This and other images of the stakes were published across the newspapers with captions including:

(13) BARRICADE: The deadly line of sharpened wooden stakes aimed chest high at police horses (Daily Mirror, 19.6.1984)

(14) Battle lines drawn: Orgreave resembles a medieval battleground with angled stakes set up by pickets against the police horses. (Times, 19.06.1984).

Although such barricades were used by both German and allied forces during World War I, in popular British conception they are associated primarily with German defences in the Battle of the Somme. The image thus accesses a specific WORLD WAR I frame via the element PLACE: SOMME. The visual metaphor invoked therefore serves to attribute to the striking miners a status of 'brutal enemy' similar to that held for German soldiers in World War I. Moreover, where the Battle of the Somme is often taken to epitomise the horrors of the First World War and the senseless loss of life it involved, the metaphor serves to undermine the strike by presenting it as equally senseless, creating a great deal of suffering with very little to gain. This particular framing reflects a wider narrative presented by the media of the strike as a hopeless effort made in vein.

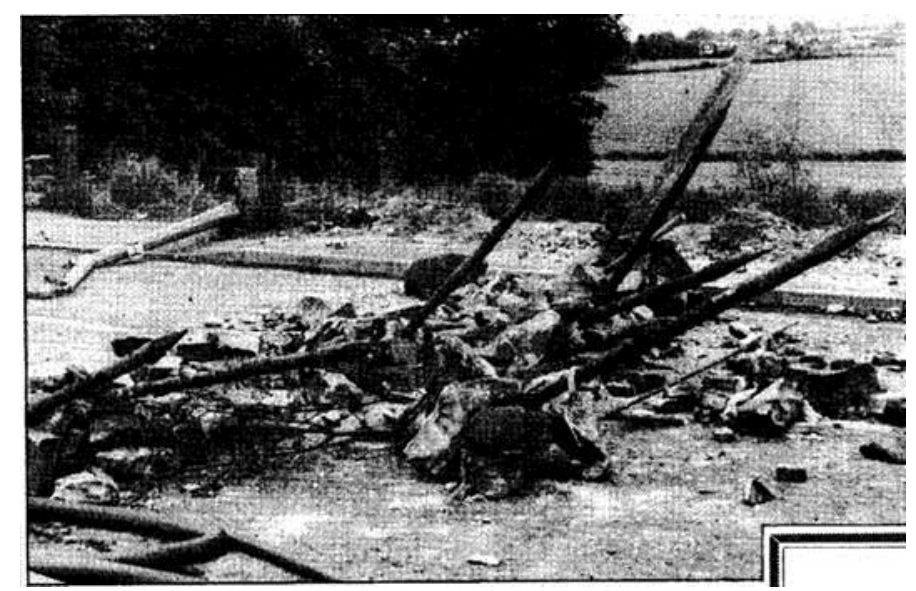

Figure 4. Wooden barrier at 'Battle of Orgreave'

(Daily Mirror, 19.6.1984)

While the images in Figures 3 and 4 remind us of the devastation caused by war, the image in Figure 5 depicts a moment of peace and humanity. The image makes an intertextual reference to an iconic image of the 1914 Christmas Day football match, which took place in 'No Man's Land' between German and allied trenches. This event is in fact much mythologised, in Barthes' (1972) sense, and unlikely to have taken place the way school history books suggest. Nevertheless, the myth provides a regular reference point in contemporary culture. ${ }^{4} \quad$ In this image, then, the historical myth is being redeployed (see Kelsey 2015) to provide a frame for understanding the current target situation. It invokes a STRIKE IS WAR metaphor by drawing equivalences between No Man's Land in World War I and the fields surrounding collieries involved in the strike. This is evidenced by the caption accompanying the image:

\footnotetext{
${ }^{4}$ It featured, for example, in a recent Christmas TV commercial for Sainsbury's supermarket.
} 
Pre-proof version. Manuscript accepted for publication in Discourse \& Communication.

(15) COME ON, YOU BLUES: A police officer keeps control as three strikers converge on him in a football match played on no-mans land during a break from picketing at the Bilsthorne colliery (Guardian, 17.03.1984)

While the image, notable for being published exclusively in the Guardian, is arguably more optimistic, presenting the human side of the strike, it is clear that the Guardian is still operating within a war framing.

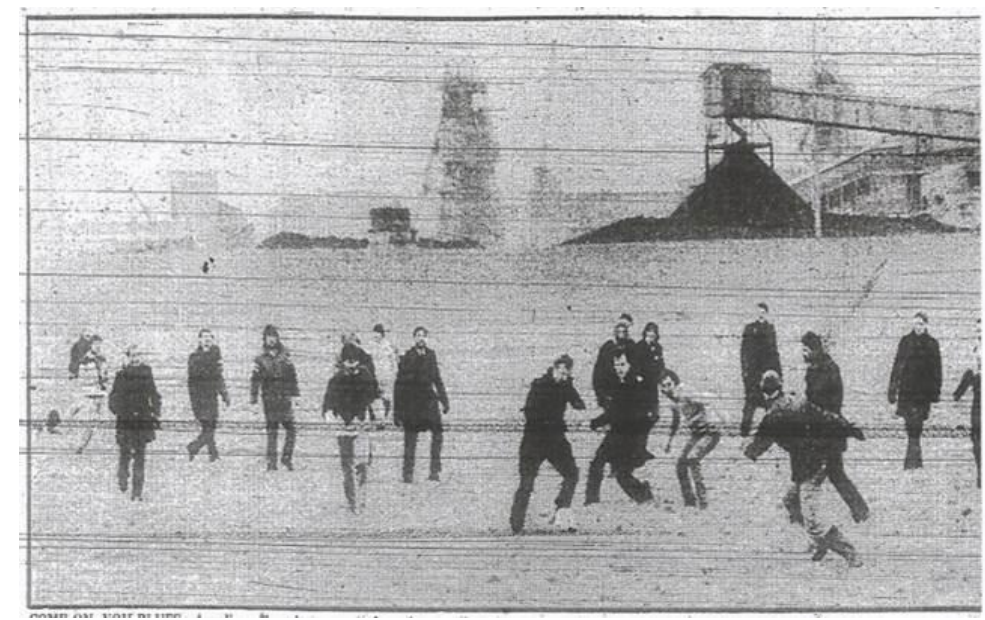

Figure 5. Police and miners playing football outside Bilsthorne colliery

(Guardian, 17.3.1984)

In a similar way, despite standing out as the only newspaper to strongly and consistently take a stance in support of the striking miners, the Morning Star is also found to operate within the same metaphorical framing. In Figure 6, for example, the police are shown in action emerging from a ditch. Again, the image accesses a frame for World War I through the frame element of PLACE. In the metaphorical reading of the image, the police officers are construed as soldiers going over the parapet of a trench. This metaphorical potential is realised through the phrase in the caption 'going over the top':

(16) Police in riot gear going over the top against miners at Orgreave yesterday (Morning Star, 30.05.1984)

In the context of this image, this polysemous phrase seems to serve at least two functions. In modern usage, the phrase means something equivalent to 'going too far' and therefore serves to appraise the actions of the police as extreme (the headline on the page reads "Scargill plea: help us stop police brutality"). However, the phrase is also irrevocably associated with going 'over the top' of the trenches and into the killing fields during World War I. The intertextuality of this phrase therefore also serves to anchor the image firmly within a war framing. 


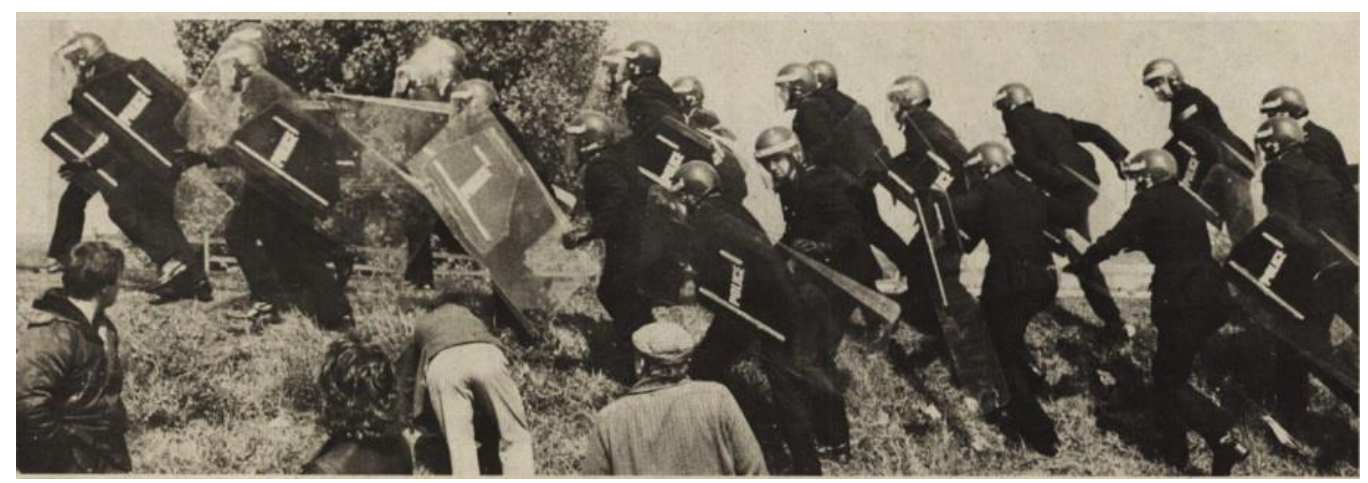

Figure 6. First use of riot gear at Orgreave

(Morning Star 30.05.1984)

\subsection{PARTICIPANTS}

Police and striking miners were both depicted as soldiers. The police in particular were shown in military-like configurations. In Figure 7, for example, the police are seen in a configuration suggestive of a military drill or parade. This image was published in several different newspapers whose captions all serve to reinforce this metaphorical reading:

(17) The war weary men in blue brace themselves for another onslaught (Express, 19.6.1984)

(18) Massed ranks of police confront the pickets (Times, 19.06.1984)

(19) BATTLE FORMATION: The massed ranks of police at Orgreave, confronting pickets trying to stop coal leaving the plant (Guardian, 19.6.1984)

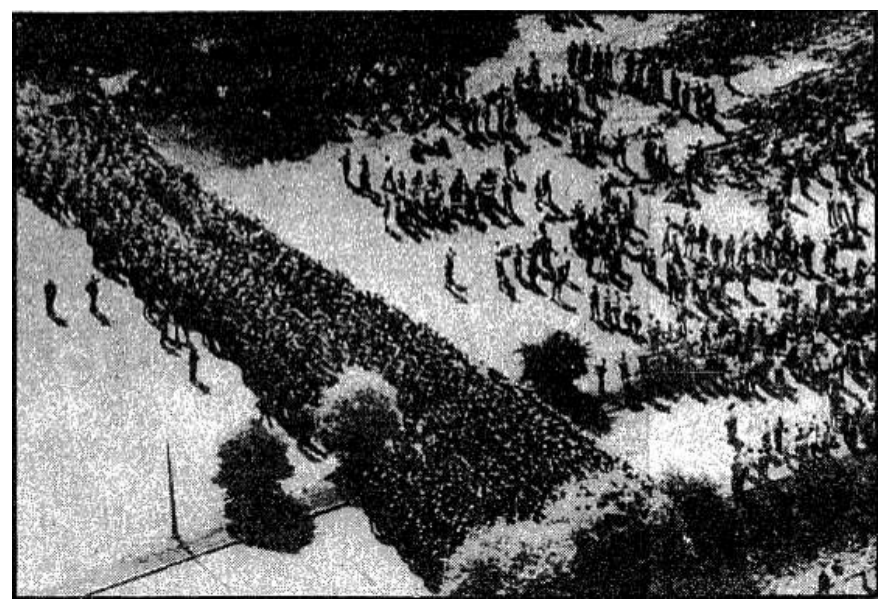

Figure 7. Mobilisation of police (Guardian, 19.6.1984)

The density and uniformity of the police, which itself contributes to the military framing, serves to legitimise the police by presenting them as disciplined and their actions as coordinated. This is reinforced by references in intra-textual context to military strategy. By contrast, the dispersal of miners in the image suggests an unorganised 'rabble' rather than a highly trained state army (for 
Pre-proof version. Manuscript accepted for publication in Discourse \& Communication.

similar analyses of real war photographs see Machin 2007). The aerial shot presented by the image, moreover, is a point of view associated with war coverage where it serves to detach the viewer from the effects of the conflict (Chouliaraki 2006; see also Kress and van Leeuwen 2006). This is in contrast to images of the miners in action where, as in Figure 8 , the point of view is from on the ground with the reader, on the horizontal plane, positioned in direct confrontation with the miners. The reader is therefore imagined as being on the receiving end of the action in the image (see Kress and van Leeuwen 2006 on point of view in images). The image in Figure 8 was published in The Sun, accompanied by the headline in (20), and in the Daily Mirror, accompanied by the caption in (21):

(20) Pickets go to war with pole. (The Sun, 31.05.1984)

(21) CHARGE: Miners advance on police after ripping down a telegraph pole as the picket at Orgreave coke works turned into a riot yesterday. (Daily Mirror, 31.05.1984)

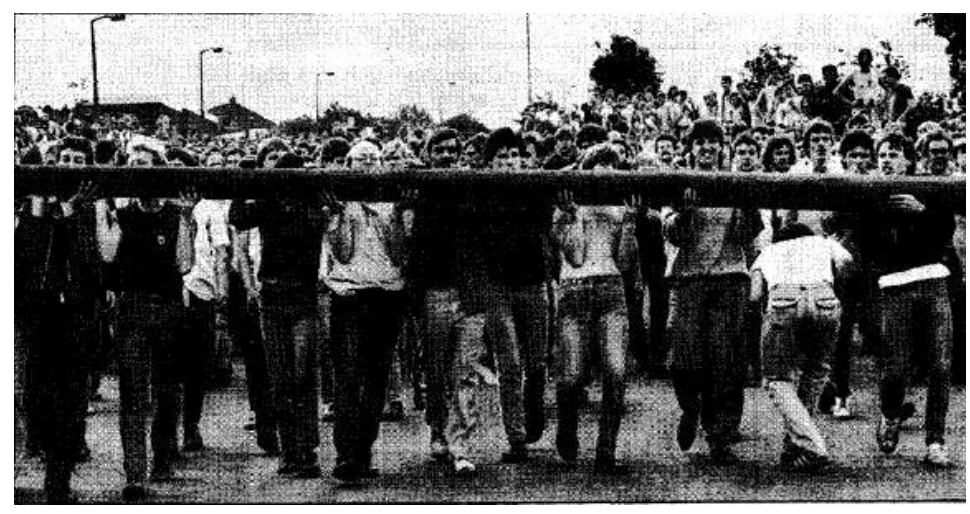

Figure 8. First use of riot gear at Orgreave: pickets holding long pole

(The Sun, 31.05.1984)

It is worth noting that the Morning Star also published a picture of the police in military-like formation, accompanied by the caption in (22), but from a point of view on the ground and with a near-frontal angle as in Figure 9. In the Morning Star, thus, it is the police rather than the miners with whom the reader is placed in conflict.

(22) INTO BATTLE: Ranks of police marching into position against the pickets outside the Orgreave coking plant. (Morning Star, 30.05.1984) 


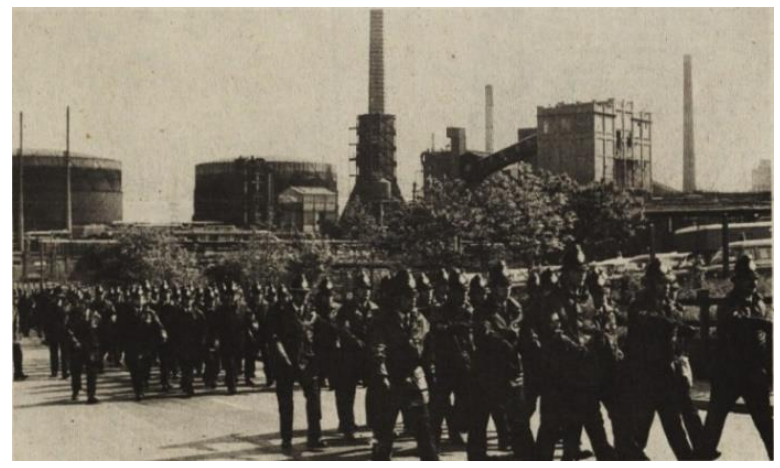

Figure 9. First use of police riot gear at Orgreave (Morning Star, 31.05.1984)

A further recurrent theme which accesses the WAR frame via PARTICIPANTS is images of both individual police officers and miners as 'injured soldiers' as in Figures 10 and 11 . While the images of police formations in Figures 7 and 9 are probably sufficient to evoke a WAR frame regardless of their textual context, the war framing in Figures 10 and 11 seems to be more dependent on intertextual context. In both cases, however, the WAR frame is supplied in the caption. The images in Figures 10 ad 11 are therefore examples of multimodal rather than pictorial metaphor. In Figure 10, as published by the Express, the WAR frame is evoked by the phrase 'wounded in battle':

(23) Wounded in battle: Blood pours from a picket injured as fighting raged under a barrage of bricks and metal bars. (Express, 19.06.1984)

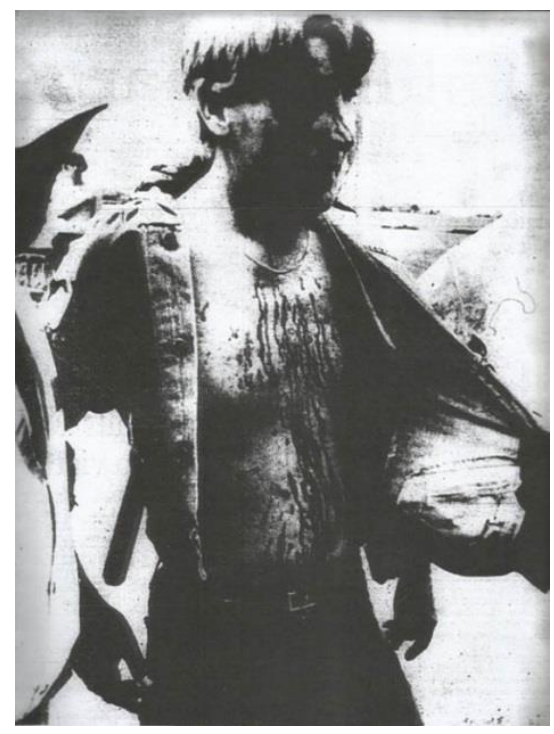

Figure 10. Injured miner at 'Battle of Orgreave'

(The Express, 19.06.1984)

Figure 11 shows the front cover of The Sun published at the end of the strike. The war framing relies on an intertextual reference in the headline phrase 'lest we forget'. This phrase comes originally from the poem Recessional written by Rudyard Kipling in 1897 and refers to the sacrifice of Christ. 
Pre-proof version. Manuscript accepted for publication in Discourse \& Communication.

However, it is reused in the Ode to Remembrance, added as a final line to Laurence Binyon's poem For the Fallen, written in 1914 in honour of British soldiers who had already lost their lives in World War I. The phrase remains associated with the First World War in particular. This intertextual reference, then, coupled with the picture of the blooded police officer, evokes a STRIKE IS WAR metaphor in which the efforts of police officers in the strike are compared with the sacrifice of British soldiers in World War I.

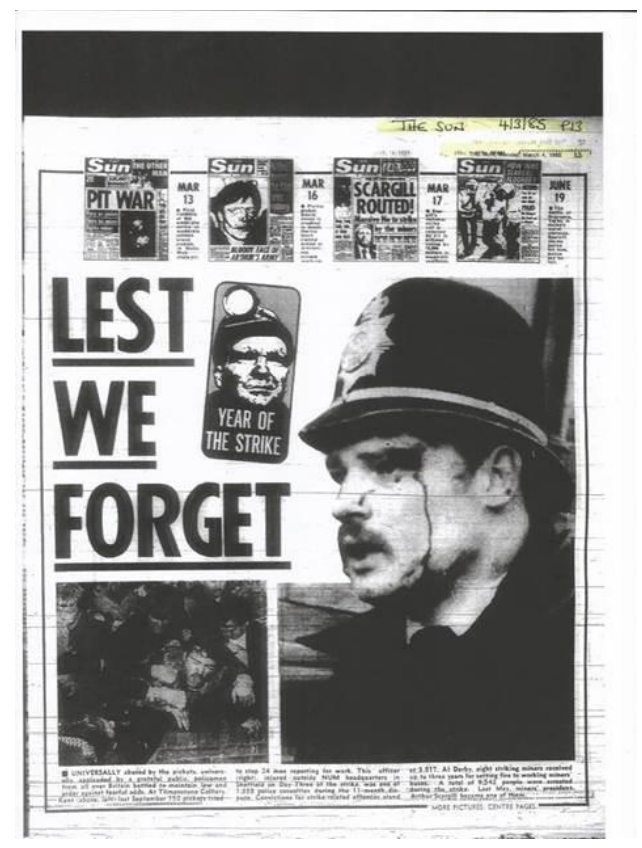

Figure 11. Front cover of The Sun at the end of the strike

(The Sun, 04.03.1984)

\subsection{INSTRUMENT/MEANS}

The final theme to emerge from the data concerns the INSTRUMENT/MEANS element of the WAR frame. Recurrent pictures of police on horseback are reminciscant of early forms of warfare in general but perhaps most canonically in popular culture mounted warfare is associated with World War I. Images such as found in Figures 12 and 13 are thus likely to access a WAR frame, and specifically a WORLD WAR I frame, via the INTRUMENT/MEANS element. Images of mounted police recur frequently throught the data where they often occur with captions involving reference to other INSTRUMENT/MEANS aspects of the WAR frame such as 'missiles'. For example, the image in Figure 12, which was published in both the Times and the Express, was accompanied by the captions in (24) and (25) respectively.

(24) Mounted police swinging into action against missile-hurling pit pickets at Orgreave yesterday (Times, 30.5.1984)

(25) Into action: Mounted police scatter pickets after officers had faced barrages of bottles, stones and deadly new missiles (Express, 30.5.1984) 


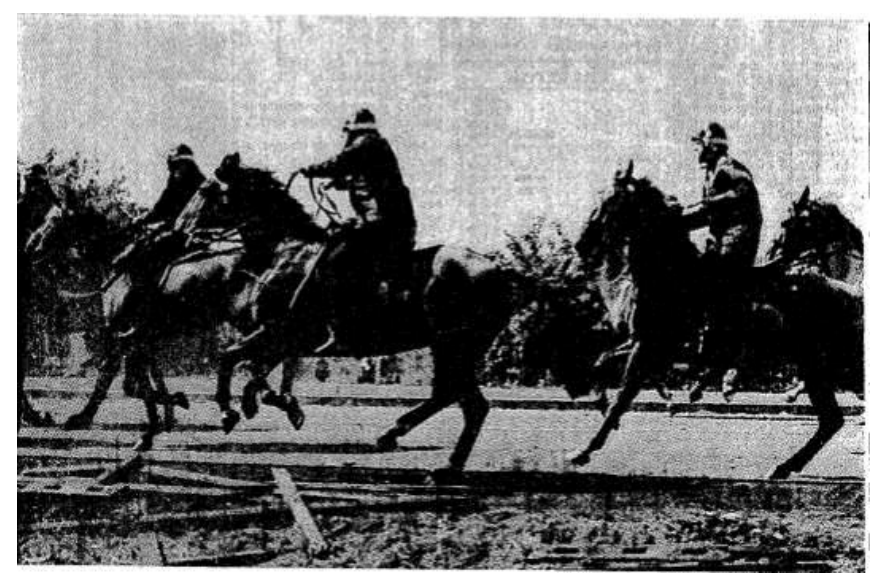

Figure 12. Mounted police at Orgreave (29.05.1984)

In contrast to the tactics of the miners shown in Figures 4 and 8 , as well as images of miners throwing 'missiles', images of police on horseback suggest a means of warfare that might be considered more 'noble'. Reporting the 'battle of Orgreave', the front cover of The Sun showed mounted police accompanied simply with the headline 'CHARGE' as in Figure 13. The lead paragraph appraised the police action as 'an amazing cavalry charge on picketing miners'.

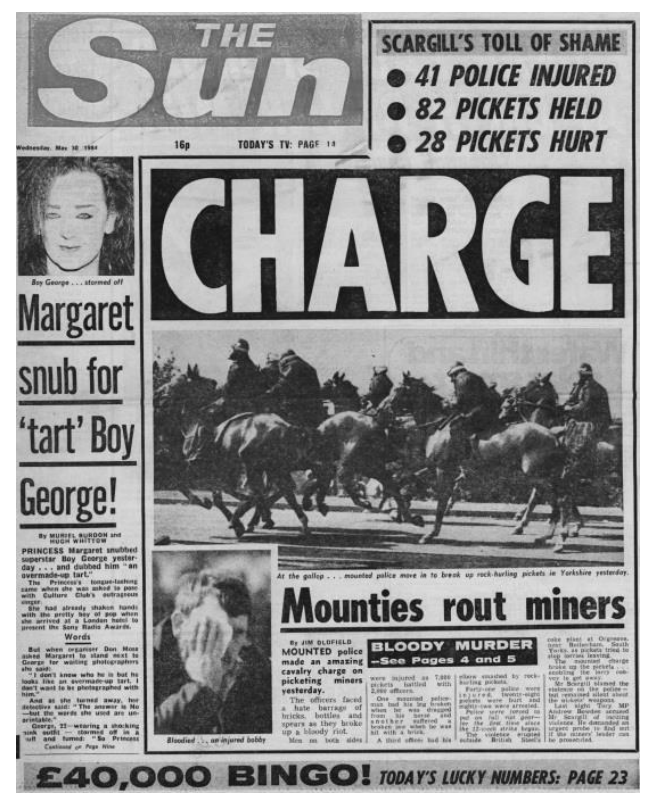

Figure 13. The Sun front cover (30.05.1984)

Other similar images of police on horseback appeared with the caption 'Charge of the blue brigade' (Telegraph, 31.05.1984), as in Figure 14, as well as headlines 'Charge of the coke brigade' (Express 30.05.1984) and 'Charge of the riot brigade' (Daily Mirror, 30.05.1984). The conventionalised construction "Charge of the X brigade" is in fact an intertextual reference to The Charge of the Light Brigade in the Crimean War. The controversial charge resulted in heavy defeat for the British cavalry and the commanders responsible are regarded as having been reckless. Regardless of this, the event is celebrated in Lord Alfred Tennyson's (1854) poem The Charge of the Light Brigade for the courage 
Pre-proof version. Manuscript accepted for publication in Discourse \& Communication.

shown by the cavalry. When presented with intertextual references to The Charge of the Light Brigade, then, a specific frame for the Crimean War becomes available with the potential inference that the 'charge' at Orgeave was similarly reckless. This inference, however, would require quite specific historical knowledge which the majority of readers are unlikely to possess. Instead, the phrase is likely to be more vaguely associated with bravery in cavalry warfare but without any specific connection to events in the Crimean War. Where mounted warfare is more saliently associated with World War I, it is this framing that is is likely to remain with the intertextual reference simply serving to appraise the efforts of the police as valorous and heroic. This evaluation is emphasised in the surrounding inter-textual context of the Daily Express with subheadings in a double-page spread:

THE BATTLE OF ORGREAVE: THE DAY MOUNTED POLICE RODE INTO ACTION TO TURN BACK 7,000 STRIKERS (Daily Express, 30.05.1984)

(27) Cheers for the brave horse patrols (Daily Express, 30.05.1984)

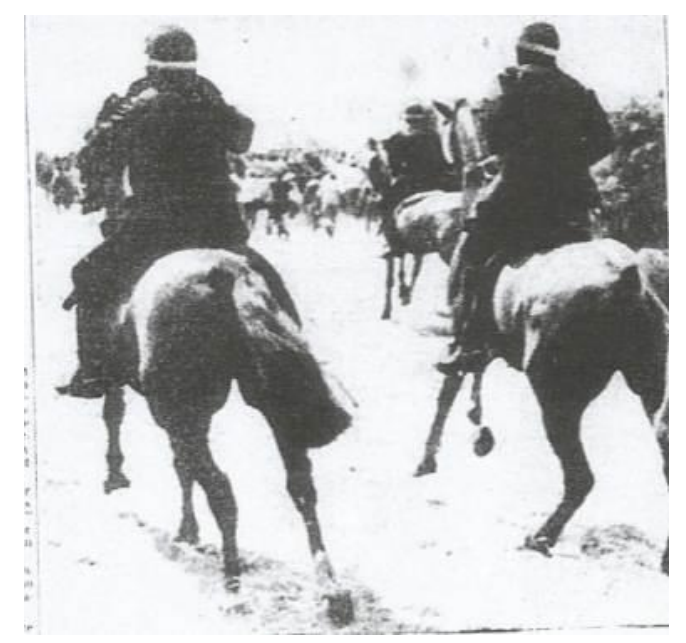

Figure 14. Mounted police at Orgreave (29.05.1984)

\section{Discussion and Conclusions}

In this paper, a STRIKE IS WAR metaphor has been shown as a persistent feature of media framing efforts throughout the (1984-85) British Miners' Strike. This metaphorical framing was enacted in both language and image as well as combinations of them. The paper therefore further evidences Forceville's (2006: 381) claim that metaphors "occur non-verbally and multimodally as well as verbally". Although many of the images analysed do not on their own necessarily suggest a STRIKE IS WAR metaphor, when interpreted in light of one another, as well as with reference to the wider discursive context of which they are a part, the data provides sufficient semiotic evidence of an underlying conceptual metaphor STRIKE IS WAR. Such a discourse-lead study of metaphor and framing thus also contributes to media studies where, as de Vreese (2005: 52) notes, there is a risk that studies 
Pre-proof version. Manuscript accepted for publication in Discourse \& Communication.

do not provide any evidence or discussion of the use of the frame in actual news reports. The pitfall of such studies is that we cannot infer whether the frames are in fact, in the words of Capella Jamieson (1997: 47) 'commonly observed in journalistic practice'.

In the news photographs analysed, the war framing is often found to be realised through a specific frame for World War I. ${ }^{5}$ In some cases, such as the injured policeman in Figure 11 or the 'battleground' scenes in Figures 3 and 4, the metaphorical reading seems to be entirely dependent on linguistic expressions in the intra-textual context of the image. That is, the source frame of WAR is supplied exclusively by immediate or surrounding co-text, without which the war framing is unlikely to arise. In other cases, such as the image of a football match between police and miners in Figure 5, the image so closely resembles other iconic images of war that, given the requisite historical knowledge, the image alone is sufficient to evoke a WAR frame. Thus, we find examples of true 'multimodal metaphor' as described within Forceville's (2008) typology but also examples of straight visual or pictorial metaphor in which the image, in of itself and as a whole, acts as a metaphorical trigger. Of course, this is not to say that the same metaphorical framing in such cases is not also converged on linguistically in intra-textual context. The boundary between multimodal and this holistic form of pictorial metaphor is therefore rather blurred. And indeed, many of the images in the data seem to fall somewhere between the two, suggesting that the distinction is best thought of as a scale. Many images in the data, then, may be said to have a potential metaphorical reading, which may be activated only weakly by the image alone (and would not necessarily be activated at all in other discursive environments) but which is strengthened as a function of intra-textual and/or inter-textual context. This, I suggest, is the case for pictures of mounted police as in Figures $12-14$ and the pictures of mobilised police forces in Figures 7 and 9.

For many images in the data, the metaphorical interpretation is realised through intertextual references either in the image itself or in accompanying language. That is, intertextuality provides a vehicle for metaphorical understanding. As Werner (2004) states, the "echoing of themes, quotations, symbols, storylines, or compositional elements from older images and famous written texts may create visual metaphors". This is the case for the football match image in Figure 5 and the image of an injured policeman accompanied by the phrase 'lest we forget' in Figure 11. In such cases, the metaphorical realisation depends on the reader recognising the intertextual reference. Again, as Werner (2004) puts it: "allusions to historical events and personages, or to past cultural texts (e.g. poems, novels, famous quotations, art), are only successful if the reader is able to access the allusionary base from which the analogies are drawn". When they are not, intertextuality is divisive and serves to create an elite in-group who are able to make the connections and who are held in contrast to an out-group lacking the same cultural capital (ibid.). In other instances of intertextuality, however, such as found in the construction 'charge of the $\mathrm{X}$ brigade' accompanying the image of mounted police in Figure 14, the framing seems to rely precisely on the reader not having sufficient historical knowledge to completely recover the intertextual reference, since this may lead to incongruities with other framing efforts, but instead having just enough knowledge for a more general WAR frame to be evoked.

From a critical perspective, motivation for framing the miner's strike as a war is likely to be a consequence of the political economy of the media. In Cognitive Linguistics, however, 'motivation' is traditionally taken to mean something slightly different. Here, motivation does not refer to why particular semiotic choices are made but to why those choices are available in the first place

\footnotetext{
${ }^{5}$ See Hart (2014a) for the way an alternative genre of political cartoons framed the strike in terms of World War II.
} 
Pre-proof version. Manuscript accepted for publication in Discourse \& Communication.

(Radden and Panther 2004). Grady (1999) identifies two primary types of motivation for metaphor: correlation and resemblance. ${ }^{6}$ Correlation metaphors are those that can be traced back to associations made in embodied experience, such as between quantity and verticality giving rise to the conceptual metaphor MORE IS UP. Resemblance metaphors are those motivated by a perceived similarity between aspects of the source and target frames. From this perspective, media efforts to frame the strike as a war may have been motivated, at least in part, by perceived similarities with the WAR frame. A number of potential similarities may be identified. For example, at the level of event-structure, a VIOLENT ENCOUNTER frame is instantiated in both acts of war and the violent scenes witnessed on the picket line. The WAR frame, in other words, may be made available via its entailed frame VIOLENT ENCOUNTER which figures in our literal understanding of the target situation. Similarly, actions of flying pickets bear a resemblance to acts of invasion in so far as both involve one group of people entering the 'territory' of another. And, at a more encyclopaedic level, both World War I and the 'Battle of Orgreave' involved horses.'

The war framing, then, may be licensed by some perceived commonalities with the target situation but there is also an element of rhetoric in selecting the WAR frame over others equally available. The WAR frame is highly evocative, serving to stir emotions and stimulate action. This is especially the case in visual and multimodal metaphors making intertextual references to iconic images associated with World War I. As Bednarek and Caple (2012: 116) state, such iconic images

function as symbolic representations of key moments in history. This iconic status comes through most clearly in war photography, with the many wars of the twentieth and twentyfirst centuries providing key critical moments that since become embedded in the national psyche, symbols of nationalism and even at times used for propaganda purposes ... Iconic images of this nature can be deployed to galvanize a particular social group to support or resist a particular action.

Framing the strike as a war, moreover, results in particular metaphorical entailments which serve to delegitimize the NUM and the striking miners while legitimizing the Government and the police. For example, the general WAR frame entails an opposition between two sides, one of whom is seen as 'the enemy'. As Wolf and Polzenhagen (2003) point out, there is therefore an inherent ideological dimension within the WAR frame as to which role a given participant is assigned. With the exception of the Morning Star, as signalled, for example, by the point of view presented in Figure 9, it is the striking miners who are cast in the role of the enemy. ${ }^{8}$ From this perspective within the frame, references to World War I in particular serve to legitimize the Government's resolve to 'defeat' the NUM, where among the British population it is generally accepted that 'our' involvement in World

\footnotetext{
6 See also Koller (2002) and Semino (2009) on 'topic-triggered' and 'situationally-triggered' metaphors respectively.

${ }^{7}$ A further source of motivation may come from the conventional conceptual metaphor ARGUMENT IS WAR (Lakoff and Johnson 1980). Given this conventional conceptual metaphor, legal and political negotiations between the NUM and the Government, as an argumentative genre, are unsurprisingly conceptualised in terms of the WAR frame (see also Wolf and Polzenhagen 2003 on international trade negotiations framed as war). This may, in turn, make the WAR frame readily available to construe other dimensions of the strike.

${ }^{8}$ The STRIKE IS WAR metaphor is not restricted in use to the media but also features in the discourse of both the Government and the NUM. This particular entailment is most famously exploited when Margret Thatcher referred to the striking miners as "the enemy within". In 1985, the NUM press officer wrote in the Guardian that "the industrial correspondents, along with broadcasting technicians, are basically our enemies' front line troops ... responsible for a cyclone of vilification, distortion and untruth".
} 
Pre-proof version. Manuscript accepted for publication in Discourse \& Communication.

War I, while devastating, was a necessary endeavour. Metaphor is therefore revealed as one semiotic resource through which an anti-trade union agenda was realised in media reports of the miners' strike. And although newspapers like the Morning Star adopted a different perspective within the STRIKE IS WAR metaphor, they are nevertheless found to make use of the WAR frame as a dominant means of understanding the strike. Regardless of perspective, this metaphorical framing serves to reduce a complex situation to a simple scenario with a restricted set of goals and outcomes. In so doing, the metaphor precludes the possibility of compromise and resolution. Had the media employed a different metaphor, it might have been possible to imagine the strike taking a different course and, ultimately, having a different outcome.

\section{References}

Barthes, R. (1972). Mythologies. New York: Noonsday Press.

Barthes, R. (1977). Image Music Text. London: Fontana Press.

Bednarek, M. and H. Caple (2012). News Discourse. London: Continuum.

Bounegru, L. and C. Forceville (2011). Metaphors in editorial cartoons representing the global financial crisis. Visual Communication 10 (2): 209-229.

Cameron, L. (2007). Patterns of metaphor use in reconciliation talk. Discourse and Society, 18 (2), 197-222.

Charteris-Black, J. (2004). Corpus Approaches to Critical Metaphor Analysis. Basingstoke: Palgrave Macmillan

Charteris-Black, J. (2006). Politicians and Rhetoric: The Persuasive Power of Metaphor. Basingstoke: Palgrave.

Chilton, P. (1996). Security Metaphors: Cold War Discourse from Containment to Common House. New York: Peter Lang.

Chouliaraki, L. (2006). The aestheticization of suffering on television. Visual Communication 5 (3): 261-285.

De Vreese, C.H. (2005). News framing: Theory and typology. Information Design Journal + Document Design 13 (1): 51-62.

Demmen, J., E. Semino, Z. Demjén, V. Koller, A. Hardie, P. Rayson and S. Payne (2015). A computerassisted study of the use of Violence metaphors for cancer and end of life by patients, family carers and health professionals. International Journal of Corpus Linguistics 20 (2): 205-231.

Dirven, R., R. Frank and M. Pütz (eds.) (2003). Cognitive Models in Language and Thought: Ideology, Metaphors and Meanings. Berlin: Mouton de Gruyter.

Dirven, R., F. Polzenhagen and H.-G. Wolf (2007). Cognitive linguistics, ideology and critical discourse analysis. In D. Geeraerts and H. Cuckyens (eds.), The Oxford Handbook of Cognitive Linguistics. Oxford: Oxford University Press. pp. 1222-1240. 
Pre-proof version. Manuscript accepted for publication in Discourse \& Communication.

Dor, D. (2003). On newspaper headlines as relevance optimizers. Journal of Pragmatics 35 (5): 695721.

El Refaie, E. (2001). Metaphors we discriminate by: Naturalized themes in Austrian newspaper articles about asylum seekers. Journal of Sociolinguistics 5 (3): 352-71.

El Refaie, E. (2003). Understanding visual metaphor: The example of newspaper cartoons. Visual Communication 2 (1): 75-96.

Fauconnier, G. and M. Turner (2002). The Way We Think: Conceptual Blending and the Mind's Hidden Complexities. New York: Basic Books.

Fillmore, C. (1982). Frame semantics. In Linguistics Society of Korea (eds.), Linguistics in the Morning Calm. Seoul: Hanshin Publishing Co. pp. 111-37.

Fillmore, C. (1985). Frames and the semantics of understanding. Quaderni di Semantica VI (2):222254.

Forceville, C. (1996). Pictorial Metaphor in Advertising. London: Routledge.

Forceville, C. (2002). The identification of target and source in pictorial metaphors. Journal of Pragmatics 34 (1): 1-14.

Forceville, C. (2006). Non-verbal and multimodal metahphor in a cognitivist framework: Agendas for research. In G. Kristiansen, M. Achard, R. Dirven and F.J. Ruiz (eds.), Cognitive Linguistics: Current Applications and Future Perspectives. Berlin: Mouton de Gruyter. pp. 372-402.

Forceville, C. (2008). Metaphor in pictures and multimodal representations. In R.W. Gibbs, Jr (ed.), The Cambridge Handbook of Metaphor and Thought. Cambrdige: Cambridge University Press. pp. 462-82.

Forceville, C. and E. Urios-Aparisi (eds.) (2009). Multimodal Metaphor. Berlin: Mouton de Gruyter.

Fridolfsson, C. (2008). Political protest and metaphor. In T. Carve and J. Pikalo (eds.), Political Language and Metaphor: Interpreting and Changing the World. London: Routledge. pp. 132148.

Gibbs, R. and L. Cameron (2008) The social cognitive dynamics of metaphor performance. Journal of Cognitive Systems Research 9 (1-2): 64-75.

Goatly, A. (2007). Washing the Brain: Metaphor and Hidden Ideology. Amsterdam: John Benjamins.

Grady, J. (1999). A typology of motivation for conceptual metaphor: Correlation vs. resemblance. In G. Steen and R. Gibbs (eds.), Metaphor in Cognitive Linguistics. Amsterdam: John Benjamins. pp. 79-100.

Harcup, T. (2014). Reporting the next battle: Lessons from Orgreave. In G. Williams (ed.), Settling Scores: The Media, the Police \& the Miners' Strike. London: Campaign for Press \& Broadcasting Freedom. pp. 95-105.

Hart, C. (2010). Critical Discourse and Cognitive Science: New Perspectives on Immigration Discourse. Basingstoke: Palgrave.

Hart, C. (ed.) (2011). Critical Discourse Studies in Context and Cognition. Amsterdam: John Benjamins. 
Pre-proof version. Manuscript accepted for publication in Discourse \& Communication.

Hart, C. (2014a). Discourse, Grammar and Ideology: Functional and Cognitive Perspectives. London: Bloomsbury.

Hart, C. (2014b). Construal operations in online press reports of political protests. In C. Hart and P. Cap (eds.), Contemporary Critical Discourse Studies. London: Bloomsbury. pp. 167-188.

Hart, C. (2015). Discourse. In E. Dabrowska and D. Divjek (eds.), Handbook of Cognitive Linguistics. Berlin: Mouton De Gruyter. pp. 322-346.

Hart, C. (2016). The visual basis of linguistic meaning and its implications for critical discourse analysis: Integrating cognitive and multimodal approaches. Discourse \& Society 27 (3): xx-xx.

Kelsey, D. (2015). Media, Myth and Terrorism: A Discourse-Mythological Analysis of te 'Blitz Spirit' in British Newspaper Responses to the July $7^{\text {th }}$ Bombings. Basingstoke: Palgrave.

Koller, V. (2002). 'A shotgun wedding': Co-occurrence of war and marriage metaphors in mergers and acquisitions discourse. Metaphor and Symbol 17: 179-203

Koller, V. (2004). Metaphor and Gender in Business Media Discourse: A Critical Cognitive Study. Basingstoke: Palgrave.

Koller, V. (2005a). Critical discourse analysis and social cognition: Evidence from business media discourse. Discourse \& Society 16 (2): 199-224.

Koller, V. (2005b). Designing cognition: Visual metaphor as a design feature in business magazines. Information Design Journal and Document Design 13 (2): 136-150.

Koller, V. (2009). Brand images: multimodal metaphor in corporate branding messages. In C. Forceville and E. Urios-Aparisi (eds), Multimodal Metaphor. Berlin: De Gruyter. pp. 45-71.

Kress, G. and T. Van Leeuwen (2006). Reading Images: The Grammar of Visual Design. 2nd edn. London: Routledge.

Lakoff, G. and M. Johnson (1989). Metaphors We Live by. Chicago: University of Chicago Press.

Lakoff, G. and M. Johnson (1999). Philosophy in the Flesh: The Embodied Mind and its Challenge to Western Thought. New York: Basic Book.

Machin, D. (2007). An Introduction to Multimodal Analysis. London: Bloomsbury.

Montgomery, M. (1995). An Introduction to Language and Society, $2^{\text {nd }}$ edn. London: Routledge.

Murdock, G. (1973). Political deviance: The press presentation of militant mass demonstration. In S. Cohen and J. Young (eds.), The Manufacture of News: Deviance, Social Problems and the Mass Media. London: Constable. pp. 206-225.

Musolff, A. (2004). Metaphor and Political Discourse: Analogical Reasoning in Debates about Europe. Basingstoke: Palgrave.

Musolff, A. (2006). Metaphor scenarios in public discourse. Metaphor and Symbol 21 (1): 23-38.

Musolff, A. (2011). Migration, media and 'deliberate' metaphors. Metaphrik.de 21: 7-19.

Radden, G. and K-U. Panther (ed.) (2004). Studies in Linguistic Motivation. Berlin: Muuton de Gruyter. 
Pre-proof version. Manuscript accepted for publication in Discourse \& Communication.

Ruppenhofer, J., M. Ellsworth, M.R.L. Petruck, C.R. Johnson and J. Scheffczyk (2010). FrameNet II: Extended Theory and Practice. Available at: https://framenet2.icsi.berkeley.edu/docs/r1.5/book.pdf

Schilperoord, J. and A. Maes (2009). Visual metaphoric concptualization in editorial cartoons. In C. Forceville and E. Urios-Aparisi (eds.), Multimodal Metaphor. Berlin: Mouton de Gruyter. pp. 213-242.

Semino, E. (2008). Metaphor in Discourse. Cambridge: Cambridge University Press.

Semino, E. (2009). Metaphor and situational motivation. Quaderns de Filologia. Estudis lingüístics. Vol. XIV: 221-233

Sperber, D. and D. Wilson (1995). Relevance: Communication and Cognition, $2^{\text {nd }}$ edn. Oxford: Blackwell.

Stockwell, P. (1999). Towards a critical cognitive linguistics. In A. Combrink and I. Bierman (eds.), Discourses of War and Conflict. Potchefstroom: Ptochefstroom University Press. pp. 510-28.

Van Dijk, T.A. (1998). Ideology: A Multidisciplinary Approach. London: Sage.

Werner, W. (2004). On political cartoons ad social studies textbooks: Visual analogies, intertextuality and cultural memory. Canadian Social Studies 38 (2).

http://www.educ.ualberta.ca/css/Css_38_2/ARpolitical_cartoons_ss_textbooks.htm

Williams, G. (ed.) (2009a). Shafted: The Media, the Miners' Strike \& the Aftermath. London: Campaign for Press and Broadcasting Freedom.

Williams, G. (2009b). The media and the miners. In G. Williams (ed.), Shafted: The Media, the Miners' Strike \& the Aftermath. London: Campaign for Press and Broadcasting Freedom. pp. 36-46.

Williams, G. (ed.) (2014). Settling Scores: The Media, the Police \& and the Miners' Strike. London: Campaign for Press and Broadcasting Freedom.

Wolf, H. G. and F. Polzenhagen (2003). Conceptual metaphor as ideological stylistic means: An exemplary analysis. In R. Dirven, R. Frank and M. Putz (eds.), Cognitive Models in Language and Thought: Ideology, Metaphors and Meanings. Berlin: Mouton de Gruyter. pp. 247-76.

Yus, F. (2009). Visual metaphor versus verbal metaphor: A unified account. In C. Forceville and E. Urios-Aparisi (eds.), Multimodal Metaphor. Berlin: Mouton de Gruyter. pp. 147-172. 